\title{
PECULIARITIES OF THE COURSE AND TREATMENT OF \\ GASTROESOPHAGEAL REFLUX DISEASE IN PATIENTS WITH SYNDROME OF UNDIFFERENTIATED TISSUE DYSPLASIA. (SYSTEMATIC LITERATURE REVIEW)
}

\author{
Iryna Romash \\ Ivano-Frankivsk National Medical University, Ivano-Frankivsk, Ukraine
}

\begin{abstract}
.
Introduction: One of the features of modern clinical medicine is that the diseases lose their mononosological character and more often have a comorbid course. Chronic pathology of the gastrointestinal tract (GIT) combined with syndrome of undifferentiated connective tissue dysplasia (UCTD) occupies a special place. And although scientists have increasingly investigated the relationship between gastroesophageal reflux disease (GERD) and UCTD syndrome in recent years, but the available scientific literature provides an extremely limited amount of material directly on the subject.
\end{abstract}

Aim: To analyze literature data on the features of the course and treatment of gastroesophageal reflux disease in patients with syndrome of undifferentiated connective tissue dysplasia.

Methods: A systematic literature search of Web of Science Core Collection, MEDLINE, PubMed, EMBASE, and the Cochrane Library until December 2019 with keywords "gastroesophageal reflux disease", "syndrome of undifferentiated connective tissue dysplasia", "ghrelin", "matrix metalloproteinase-9", "prostaglandin E2", "prostoglandin F2 $\alpha$ ", "oxyproline", "micro- and macronutrients", was performed

Results: According to scientific data, the digestive system is the second system of the body according to the frequency of involvement in the dysplastic process after the cardiovascular system (Bodolay E. et.al., 2003). The high degree of collagenation of the digestive system allows us to expect a variety of manifestations of UCTD. Dysplastic changes in the gastrointestinal tract include insufficiency of cardia, diaphragmatic hernia, ptosis of abdominal organs, anomalies of shape and structure of esophagus, stomach, duodenum, esophageal diverticula and various departments of intestines. In this case, the presence of UCTD syndrome causes certain features of metabolism, adaptation and existence of the organism in conditions of defective collagen (Nica A. E et.al., 2016).

From a clinical point of view, UCTD is a heterogeneous and polymorphic condition, which underlie various defects in the formation of collagen and elastin fibers as a result of genetic predisposition, which lead to disorders at the tissue and organism levels (Chemodanov V. and others. , 2018). Acording to the science data, assignment of patients to the UCTD group is possible if its manifestations are not specific for such connective tissue diseases as rheumatoid arthritis (RA), scleroderma, systemic vasculitis, myositis, systemic 
lupus erythematosus, Sjogren's syndrome (Antunes M. et al., 2019.) The complexity of the morphology and the variety of connective tissue functions also determine the prevalence of visceral manifestations of UCTD. Moreover, as the phenotypic signs UCTD increases, the likelihood of detecting pathological changes in the internal organs increases. The degree of damage to the internal organs and usually determines the severity of the clinical picture and individual prognosis. (Usenko O. Yu et al., 2017; Denaxas K. et.al., 2018).

GERD is a multifactorial disease in the occurrence of which play a role as a support (stress, obesity, smoking, intake of some medications, nutritional features) and determining factors that include cardiac insufficiency, gastric reflux and resistance of the mucous membrane of the esophagus due to a decrease in its clearance. The risk of developing GERD also increases with generalized or regional disruption of connective tissue structure that is widespread in the population (Kadurina T. I. et.al., 2010). Cardia insufficiency is one of the manifestations of UCTD, and there is a direct relationship between the degree of UCTD and the incidence of gastroesophageal reflux (Denaxas K. et.al., 2018).

On the background of UCTD, in combination with gastroesophageal refluxes (GER), a pronounced inflammation of the mucous membrane of the lower third of the esophagus was more often found. Frequent GER may affect the state of the autonomic nervous system through the nerve and anatomical ligaments of the esophagus and deepen connective tissue dysfunction. In some works, it was found, that on the background of UCTD syndrome, the symptoms inherent in GERD were detected more often than in patients without signs of the first. In particular, these patients complained more frequently of heartburn, severe chest pain, more frequent gastroesophageal and duodenogastric refluxes and erosion of the mucous membrane of the lower third of the esophagus. Thus, as can be seen from the above data, conditions for such important pathogenetic links of the development of GERD, such as impaired function of the lower esophageal sphincter (LES), reduction of the barrier capacity of the mucous membrane of the esophagus, an increase in the number of acid and mixed refluxes. (Kamataki A. et.al., 2015; Baia X. et. Al., 2019). The exclusive role of PGE2 in maintaining mucosal integrity, preventing acid reflux, and esophagitis by modulating various gastrointestinal functions has been scientifically validated (Baia X. et al., 2019). At the same time, in the available literature, we have not identified any studies examining the role of different classes of prostaglandins in protecting mucous membrane of the esophagus in UCTD.

Peptide hormone such as ghrelin has a pronounced effect on gastric motility. This hormone is mainly released from the stomach and has many physiological actions, such as stimulating food intake, regulating the motility of the gastrointestinal tract, stimulating the release of growth hormone, lowering blood pressure and regulating the complex process of energy metabolism, through the correction of hunger signals. As ghrelin stimulates gastric motility and accelerates gastric emptying, the effect of this intestinal hormone on GIT motility 
is being actively studied, in particular in pathological GER (Kitazawa T. et.al., 2018). At the same time, the role of ghrelin in GERD as an independent disease and its combination with UCTD has not been studied.

Involvement of the esophagus in the pathological process of UCTD is also explained by the accumulation of the extracellular matrix in its walls, remodeling and degradation of collagen and other compounds, and the key regulators of these processes, both under physiological and pathological conditions are matrix metalloproteinases (MMP's) (Chen et al., 2009). The cofactors of matrix metalloproteinases are micro- and macroelements that are involved in the formation of collagen, giving elasticity to the connective tissue matrix (Ismail AA, 2016). At the same time, the level of micro- macroelements in blood and MMP-9 activity was not studied in patients with GERD on the background of UCTD.

With regard to drug therapy of this combined pathology in adults, in cases of development of GERD on the background of UCTD pathogenetically justified complex therapy has not been developed, which also determines the relevance of this study.

Conclusion: A study of the literature on the comorbidity of GERD and UCTD has shown that variability in clinical pathology markers is not fully reflected in publications on this topic. This complicates early diagnosis, making the right diagnosis at the initial examination of the patient. The clinic for such combined pathology remains poorly understood. In this regard, the treatment of this pathology is not prophylactic, aimed at preventing possible complications, but remains symptomatic. Therefore, the next step in this study will be: to study the frequency of combination of GERD with phenotypic and biochemical markers of UCTD syndrome; establishment of features of clinical manifestations, changes in gastric motility, indicators of daily $\mathrm{pH}$-metry, condition of the mucous membrane of the lower third of the esophagus in patients with GERD in combination with syndrome UCTD.

Keywords: gastroesophageal reflux disease, syndrome of undifferentiated connective tissue dysplasia, diagnosis, ghrelin, matrix metalloproteinase-9, prostaglandins $E 2$ and $F 2 \alpha$, oxyproline, micro- and macronutrients, treatment.

The author declares that has no competing interests

\section{References}

Chernobrovyi V. M., Melashchenko S. H., Chernobrova O. I., Ksenchyn O. O. (2017) Gastroesophageal reflux disease: main accents of modern differentiated and controlled pharmacotherapy. Modern Gastroenterology, 4 (96), 33-42. 
Marushko Yu. V., Asonov A. O., Hyshchak T. V. (2019) The role of magnesium in the human body and the effect of reduced magnesium content on the quality of life of children with gastroesophageal reflux disease. Modern pediatry, 1 (97), 124-130; doi 10.15574/SP.2019.97.124.

Burduli N. M., Tadtaeva D. Ya. (2012) The effect of intravenous laser therapy on the dynamics of prostaglandins E2 and F2a and the state of microcirculation in patients suffering from gastroesophageal reflux disease. Questions of balneology, physiotherapy and physiotherapy, 6, 720.

Nechaeva G. I., Drokina O. V., Druk I. V. i dr. (2014) The main directions in the treatment of patients with connective tissue dysplasia. Therapist. Lechashhij vrach.,8, 54-56.

Sirchak Ye. S., Boldizhar O. O., Stan M. P. (2018) The role of biologically active substances in the formation of gastroesophageal reflux disease in patients with type 2 diabetes. Gastroenterologia, 52 (2), 71-76. doi: 10.22141/2308-2097.52.2.2018.132611

Usenko O. Yu., Voitiv Ya. Yu. (2017) Frequency and criteria for the diagnosis of undifferentiated connective tissue dysplasia in surgical patients. Clinical surgery, 10, 5-7.

Chemodanov V.V., Krasnova E. E. (2018) The principles of medical support for children with connective tissue dysplasia. Therapist, 66-69.

Antunes M., Scirè C. A., Talarico R. et al. (2018) Undifferentiated connective tissue disease: state of the art on clinical practice guidelines. RMD Open, 4:e000786.doi:10.1136/rmd open-2018-000786.

Baia X., Iharaa E, Otsukaa Y. et al. (2019) Involvement of different receptor subtypes in prostaglandin E2-induced contraction and relaxation in the lower esophageal sphincter and esophageal body. European Journal of Pharmacology, 857, 172405.

Castaneda F.E., Walia B., Vijay-Kumar M. et al. (2005). Targeted deletion of metalloproteinase 9 attenuates experimental colitis in mice: central role of epithelial-derived MMP. Gastroenterology, 129, (6), 1991-2008.

Denaxas K., Ladas S. D., Karamanolis G. P. (2018) Evaluation and management of esophageal manifestations in systemic sclerosis. Ann. Gastroenterol., 31(2), 165-170. doi:10.20524/aog.2018.0228.

Domingues, G., Moraes-Filho, J. P. P., Fass, R. (2018) Refractory Heartburn: A Challenging Problem in Clinical Practice. Dig Dis Sci., 63, 577-82. https://doi.org/10.1007/s10620-018-4927-5.

Ismail A.A.A., Ismail N.A. (2016) Magnesium: A mineral essential for health yet generally underestimated or even ignored. J. Nutr. Food Sci., 6, 523. DOI: 10.4172/2155-9600.1000523.

Kadurina T. I., Abbakumova L. N. (2010) Rehabilitation principles for patients with connective tissue dysplasia. Consulting physician, 40, 10-16. 
Kamataki A., Uzuki M., Sawai T. (2015). Histopathological Change of Esophagus Related to Dysphagia in Mixed Connective Tissue Disease. Seminars in Dysphagia Edited by Renee Speyer and Hans Bogaardt. Chapter 13. http://dx.doi.org/10.5772/60509

Kitazawa T, Kaiya H. (2019) Regulation of Gastrointestinal Motility by Motilin and Ghrelin in Vertebrates. Front. Endocrinol., 10, 278. doi: 10.3389/fendo.2019.00278

Kondoh, Y, Johkoh T, Fukuoka J. et.al.(2015). Broader criteria of undifferentiated connective tissue disease in idiopathic interstitial pneumonias. Respiratory Medicine, 109(3), 389-396. https://doi.org/10.1016/j.rmed.2015.01.009

Medsger T.A. Jr, Bombardieri S, Czirjak L. et. al.(2003) Assessment of disease severity and prognosis. Clin Exp Rheumatol.,21 (29), 42-46.

Nica A. E., Alexa L. M., Ionescu A. O. et al. (2016) Esophageal disorders in mixed connective tissue diseases. Journal of Medicine and Life., 9(2), 141143. PubMed PMID: 27453743; PubMed Central PMCID: PMC4863503.

Xiaoping Chen, Yong Li. (2009) Role of matrix metalloproteinases in skeletal muscle Migration, differentiation, regeneration and fibrosis. Cell Adhesion \& Migration, 3,4, 337-341. 


\section{ОСОБЛИВОСТІ ПЕРЕБІГУ ТА ЛІКУВАННЯ ГАСТРОЕЗОФАГАЛЬНОЇ РЕФЛЮКСНОЇ ХВОРОБИ У ПАЦІЕНТІВ ІЗ СИНДРОМОМ НЕДИФЕРЕНЦЙОВАНОЇ ДИСПЛАЗІЇ СПОЛУЧНОЇ ТКАНИНИ. (ОГляд літератури) \\ Ромаш Ірина Богданівна \\ Асистент кафедри пропедевтики внутрішньої медицини ДВНЗ « Івано-Франківський національний медичний університет».}

Проведено аналіз вітчизняних та закордонних літературних даних щодо особливостей перебігу та лікування гастроезофагальної рефлюксної хвороби у пацієнтів із синдромом недиферениійованої дисплазї сполучної тканини.

Ключові слова: гастроезофагальна рефлюксна хвороба, синдром недиференційованої дисплазії сполучної тканини, діагностика, грелін, матриксна металопротеїназа-9, простагландини E 2 та F2 $\alpha$, оксипролін, мікро- та макроелементи, лікування.

Постановка проблеми. Систематичний огляд наукових джерел засвідчив, що поширеність гастроезофагальної рефлюксної хвороби (ГЕРХ) серед населення становить 10-40\% (Чернобровий В. М. та ін., 2017; Усенко О. Ю. та ін., 2017). Але реальна частота цього захворювання, вочевидь, є значно вищою, аніж свідчить статистика. Це пов'язано 3 тим, що лише незначна частина пацієнтів з печією звертаються за медичною допомогою, та тим, що не всі лікарі приділяють достатню увагу цій проблемі. Важливість ГЕРХ зумовлена не тільки можливістю розвитку таких важких життєзагрозливих ускладнень, як виразки, стриктури, стравохід Баррета, аденокарциноми стравоходу, кровотечі, але й значним впливом на якість життя таких пацієнтів. Науково підтверджено, що у хворих на ГЕРХ відмічається більш виражене зниження якості життя, ніж у пацієнтів із стенокардією, цукровим діабетом. Окрім того, рецидивуючий характер захворювання сприяє зростанню термінів тимчасової та стійкої втрати працездатності, що визначає ГЕРХ не тільки як медичну, але й соціальну проблему (Domingues G. et.al., 2018).

Мета статті - провести аналіз вітчизняних та закордонних літературних даних щодо особливостей перебігу та лікування гастроезофагальної рефлюксної хвороби у пацієнтів із синдромом недиференційованої дисплазії сполучної тканини.

Матеріали і методи дослідження: Був проведений систематичний пошук та аналіз літератури в Web of Science Core Collection, MEDLINE, PubMed, EMBASE та Cochrane Library до грудня 2019 року за ключовими словами "гастроезофагеальна рефлюксна хвороба", "синдром недиференційованої дисплазії сполучної тканини", "грелін", "матрична 
металопротеїназа-9", "простагландин E2", "простагландин $\quad$ F2 $\alpha$ ", "оксипролін", "мікро- та макроелементи ".

Виклад основного матеріалу. Однією 3 особливостей сучасної клінічної медицини $є$ те, що захворювання втрачають мононозологічний характер і частіше мають коморбідний перебіг. Окреме місце займає питання хронічної патології шлунково-кишкового тракту (ШКТ) поєднане із синдромом недиференційованої дисплазії сполучної тканини (НДСТ). I хоча останні роки науковці все частіше досліджують взаємозв'язки ГЕРХ із синдромом НДСТ, можна констатувати, що доступна наукова література дає вкрай обмежений обсяг матеріалів безпосередньо з цього питання. Згідно із науковими даними, травна система друга система організму за частотою залучення до диспластичного процесу після серцево-судинної (Bodolay E. et.al., 2003). Високий ступінь колагенізації органів травлення дозволяє очікувати різноманітних проявів НДСТ. До диспластикозалезжних змін ШКТ відносяться недостатність кардії, діафрагмальна грижа, птози органів черевної порожнини, аномалії форми та будови стравоходу, шлунка, дванадцятипалої кишки, дивертикули стравоходу i різних відділів кишечника та інші. При цьому наявність синдрому НДСТ обумовлює певні особливості обміну, адаптації та існування організму в умовах неповноцінно сформованного колагену (Nica A. E et.al., 2016).

3 клінічних позицій, НДСТ - це гетерогенна за походженням і поліморфна за проявами група станів, в основі яких лежать різноманітні дефекти формування колагенових та еластинових волокон у результаті генетичної схильності, які призводять до порушення на тканинному та організменному рівнях (Чемоданов В. В и др., 2018). Віднесення хворих до групи НДСТ можливе, якщо його прояви не $є$ специфічними для таких захворювань сполучної тканини як ревматоїдний артрит (РА), склеродермія, системний васкуліт, міозит, системний червоний вовчук, синдром Шегрена (Antunes M. et. al., 2019.). Складність морфології та різноманіття функцій сполучної тканин визначають також поширеність вісцеральних проявів НДСТ. Причому, в міру збільшення фенотипових ознак, підвищується ймовірність виявлення патологічних змін у внутрішніх органах. Ступінь ураження саме внутрішніх органів і визначає, як правило, важкість клінічної картини та індивідуальний прогноз. Наявність наукових даних дозволяють стверджувати, що існує досить тісний взаємозв'язок між кількістю зовнішніх фенотипових ознак ДСТ і частотою виявлення стигм дизембріогенезу внутрішніх органів. (Усенко О. Ю та ін., 2017; Denaxas К. et.al., 2018 ).

ГЕРХ $є$ багатофакторним захворюванням у виникненні якого відіграють роль як сприяючі (стреси, робота пов'язана із частими нахилами, ожиріння, куріння, прийом деяких медикаментозних препаратів, особливості харчування) так і визначальні фактори, до яких належить недостатність кардії, рефлюкс шлункового і змішаного вмісту 3 шлунка в стравохід, 
резистентність слизової оболонки стравоходу внаслідок зниження iї кліренсу. Ризик розвитку ГЕРХ також зростає при генералізованому чи регіональному порушенні структури сполучної тканини, яка широко розповсюджена серед населення (Kadurina T. I. et.al., 2010). Одним з проявів НДСТ є недостатність кардії, а між ступенем НДСТ та частотою виникнення гастроезофагального рефлюксу існує пряма залежність (Denaxas K. et.al., 2018) Згідно досліджень Т. А. Medsger та співавторів, ураження шлунковокишкового тракту спостерігалися у 80\% пацієнтів і найчастіше вони відмічались з боку стравоходу (Medsger T.A et.al., 2003).

На тлі НДСТ у поєднанні із гастроезофагеальними рефлюксами частіше виявлялося виражене запалення слизової оболонки нижньої третини стравоходу. Часті гастроезофагальні рефлюкси можуть впливати на стан вегетативної нервової системи через нервові та анатомічні зв'язки стравоходу та поглиблювати дисфункцію сполучної тканини. В поодиноких роботах встановлено, що на фоні синдрому НДСТ, симптоми, властиві ГЕРХ, визначались частіше ніж у хворих без ознак першої. Зокрема, ці пацієнти значно частіше скаржились на печію, сильний біль за грудиною, у них частіше реєструвались гастроезофагальні та дуоденогастральні рефлюкси, виявлялись ерозії слизової оболонки нижньої частини стравоходу. Таким чином, як видно 3 наведених даних, при НДСТ створюються умови для таких важливих патогенетичних ланок розвитку ГЕРХ, як порушення функції нижнього стравохідного сфінктера, зниження бар'єрних можливостей слизової оболонки стравоходу, зростання числа рефлюксів кислим та змішаним вмістом. (Kamataki A. et.al., 2015; Baia X. et. al., 2019) .

Порушення функції нижнього стравохідного сфінктера вірогідно може сприяти формуванню постпрандіальної "кислотної кишені" - шару незабуференої соляної кислоти, що утворюється на поверхні вмісту шлунка після прийому їжі та іï переходу вище діафрагми і тривало персистувати, хоча при наявності НДСТ дане питання абсолютно не вивчено. Також при цьому зростає роль резистентності слизової оболонки стравоходу (СОС), особливо передепітеліального бар'єру, який забезпечується секретом слинних та власних залоз підслизової оболонки стравоходу та включає муцини, немуцинові протеїни, бікарбонати, простагландини класу Е 2 та F2 $\alpha$. Науково підтверджена виняткова ролі PGE2 у підтримці цілісності слизової оболонки, попередженні кислотного рефлюксу та езофагіту шляхом модуляції різних функцій ШКТ (Baia X. et. al., 2019). Наявні поодинокі дослідження щодо ролі PGE2 в захисті слизової оболонки стравоходу. Н.М. Бурдули, Д.Я. Тадтаева вивчавши зміни рівнів простагландинів класу Е2 та F2a в сироватці крові у хворих на ГЕРХ встановили зниження їх концентрації у хворих на ГЕРХ (Бурдулі Н. М. и др., 2012). За даними досліджень Сірчак Є.С. та співавторів, навпаки, виявлено підвищення рівнів PG F2 $\alpha$ у пацієнтів з ГЕРX у 2,2 рази у порівнянні зі здоровими ( Сірчак $€$. 
C. та ін., 2018). В той же час, в доступній літературі, нами не виявлено досліджень в яких вивчалась би роль різних класів простагландинів в захисті СОС при НДСТ.

На моторику шлунку виражений вплив чинить такий пептид як грелін. Цей гормон в основному вивільняється 3 шлунка і має багато фізіологічних дій, таких як стимулювання споживання їжі, регуляція моторики ШКТ, стимулювання вивільнення гормону росту, зниження артеріального тиску i регулювання складного процесу енергетичного метаболізму, шляхом корекції сигналів голоду. Оскільки грелін стимулює рухливість шлунка i прискорює його спорожнення шлунка, активно відбувається вивченння впливу цього інтестинального гормона на моторику ШКТ, зокрема при потологічних ГЕР (Kitazawa T. et.al., 2018). В той же час роль греліну при ГЕРХ як самостійному захворюванні так і їі поєднанні 3 НДСТ не вивчалась.

У синтезі основних структурних білків сполучної тканини, важливу роль відіграють мікро- та макроелементи, що $є$ кофакторами матриксних металопротеїназ. Зокрема, $\mathrm{Mg}$ впливає на активність ферментів, які приймають участь у формуванні колагену, надаючи сполучнотканинному матриксу пружність та еластичність (Ismail A.A.A, 2016). Дефіцит іонів магнію займає важливе місце серед патогенетичних механізмів формування дисплазії сполучної тканини. Зниження в організмі концентрації магнію сприяє більш важкому перебігу ГЕРХ та зниженню якості життя (Марушко Ю. В та ін., 2019). В умовах магнієвої недостатності порушується здатність фібробластів продукувати колаген та посилюється деградація колагенових волокон, відбувається синтез дефектного колагену внаслідок порушення структури його волокон, зміни співвідношення між колагеновими та еластиновими волокнами в сторону останніх та сповільнення синтезу усіх структурних молекул сполучної тканини. Дефіцит $\mathrm{Mg} 2+$ призводить до підвищення активності колагенази ММП-9, а згідно наукових даних це пришвидшує деградацію структурних компонентів внутрішньо-клітинного матриксу, в першу чергу колагену (Castaneda F. E. et. al., 2009). Залучення стравоходу до патологічного процесу при НДСТ також пояснюється накопиченням позаклітинного матриксу у його стінках, ремоделюванням та деградацією колагену та інших сполук, а ключовими регуляторами цих процесів, як при фізіологічних, так і при патологічних умовах є матриксні металопротеїнази (matrix metalloproteinase- MMP) (Xiaoping Chen. et.al., 2009). В той же час, у хворих на ГЕРХ на тлі НДСТ вивчення рівня магнію в крові та активності ММР-9 не проводилось. Порушення динамічної рівноваги між агресивними і протективними факторами також, вірогідно, сприяє деградації колагену, оскільки він є головним компонентом сполучної тканини, якою багатий підслизовий шар стінки стравоходу. Запалення слизової стравоходу внаслідок гастроезофагального та гастродуоденального рефлюксів веде до порушення сполучнотканинної структури, а стан обміну 
колагену як при самостійній ГЕРХ так і при іiі розвитку на фоні НДСТ практично не вивчені, що і зумовлює дане дослідження. В окремих роботах присвячених дослідженню особливостей перебігу інших захворювань шлунково-кишкового тракту (жовчно-кам'яної хвороби, панкреатодуоденальної патології) на тлі НДСТ з різною частотою вказується на існування у таких хворих недостатності кардії (12,6\%), гастроезофагального рефлюксу (від 4,7 \% о 10,3\%), що також підтверджує необхідність вивчення особливостей перебігу патогенетичних механізмів розвитку та пошуку нових підходів до терапії ГЕРХ на тлі НДСТ (Kondoh Y. et.al., 2015).

Що стосується медикаментозної терапії даної поєднаної патології у дорослих, то вона на відміну від дітей, майже не розроблена. Терапія самостійної ГЕРХ в першу чергу вимагає лікування тих патологічних станів, що сприяють посиленню патогенетичних ланок розвитку та призначення антирефлюксної терапії. Препаратами вибору для фармакотерапії ГЕРХ $\epsilon$ антисекреторні середники i, в першу чергу, інгібітори протонної помпи (ІПП). Також для підвищення ефективності лікування і швидкої ліквідації симптомів можуть використовуватись два шляхи, серед яких комбінація ІПП 3 альгінатами чи прокінетиками, або підвищення дози препарату. Що стосується НДСТ, то основне завдання лікування таких хворих полягає в корекції порушень метаболізму колагену. При цьому використовується терапія препаратами магнію, вітамінами, анаболічними засобами, антагоністами альдостерону та препаратами амінокислот ( Г.И. Нечаева и соавт., 2014). В той же час, у випадках розвитку ГЕРХ на тлі НДСТ патогенетично обгрунтованої комплексної терапії не розроблено, що також зумовлює актуальність даного дослідження.

Висновки і подальші перспективи дослідження: Вивчення літератури з питань коморбідності ГЕРХ і НДСТ показало, що у публікаціях на цю тему неповно відображена варіабельність клінічних маркерів патології. Це ускладнює ранню діагностику, постановку правильного діагнозу при первинному огляді пацієнта. Клініка такої поєднаної патології залишається недостатньо вивченою. У зв'язку з цим лікування даної патології не $є$ профілактичним, спрямованим на попередження можливих ускладнень, а залишається симптоматичним. Тому, наступним етапом цього дослідження буде: вивчення частоти поєднання ГЕРХ з фенотиповими та біохімічними маркерами синдрому НДСТ; встановлення особливостей клінічних проявів, змін моторики шлунка, показників добової рН-метрії, стану слизової оболонки нижньої третини стравоходу у хворих на ГЕРХ у поєднанні з синдромом НДСТ. 